\title{
Antenatal Diagnosis of Dizygotic, Monochorionic Twins Following IVF/ICSI
}

\section{Pränatale Diagnose von dizygoten, monochorialen Gemini nach IVF/ICSI}

Authors

Affiliations
P. Korsun ${ }^{1}$, M. Bals-Pratsch ${ }^{2}$, O. Ortmann ${ }^{1}$, S. Markus ${ }^{3}$, U. Germer ${ }^{1}$

${ }^{1}$ Klinik für Frauenheilkunde und Geburtshilfe der Universität Regensburg am Caritas-Krankenhaus St. Josef, Regensburg

2 Profertilita, Zentrum für Fruchtbarkeitsmedizin, Regensburg

${ }^{3}$ Kompetenzzentrum für Humangenetik, Gynäkologie und Laboratoriumsmedizin, Dr. Staber und Kollegen, Regensburg
Deutsche Version unter: http://dx.doi.org/ $10.1055 / \mathrm{s}-0042-101024$

\section{Abstract \\ $\nabla$}

Monochorionic twins are usually monozygotic and thus usually have the same sex. A case of monochorionic diamniotic twins following IVF/ ICSI and laser treatment of the zona pellucida ("assisted hatching") is presented in which partial embryo amalgamation appears to have occurred. Discordant sex between the twins was suspected on detailed antenatal ultrasound at $13+3$ weeks gestation and was confirmed on subsequent examinations. The sexual phenotype at birth was female for one twin and male for the other. Placental histology confirmed the monochorionic, diamniotic situation. Cytogenetic analysis of both twins was carried out postpartum on various tissues. On karyotyping of blood lymphocytes the male and female twins each had one mosaic of male and female cells. Oral mucosal cells showed normal male and female karyotypes respectively. Analysis of urothelium showed a normal result for the male infant, and a weak gonosomal mosaic with an $\mathrm{XX}$ and $\mathrm{XY}$ constellation for the female infant. At least for blood lymphocytes, a diagnosis of chimerism was proven.

$\begin{array}{ll}\text { received } & 4.2 .2015 \\ \text { revised } & 10.1 .2016 \\ \text { accepted } & 17.1 .2016\end{array}$

Bibliography

Dol http://dx.doi.org/ 10.1055/s-0042-101024 Geburtsh Frauenheilk 2016; 76: 727-730 @ Georg Thieme Verlag KG Stuttgart · New York . ISSN 0016-5751

\section{Correspondence}

Dr. Petra Korsun

Klinik für Frauenheilkunde und Geburtshilfe der Universität Regensburg am CaritasKrankenhaus St. Josef Landshuter Straße 65 93053 Regensburg pkorsun@caritasstjosef.de

\section{Introduction \\ $\nabla$}

Ultrasound examination of twin pregnancies can reliably distinguish between monochorionic and dichorionic placentation. Dichorionic twins have separate placentas and amniotic cavities and in $90 \%$ of cases arise from two oocytes. In contrast monochorionic twins originate strictly from one

\section{Zusammenfassung $\nabla$}

Üblicherweise sind monochoriale Zwillingsschwangerschaften monozygot und weisen dasselbe Geschlecht auf. Im vorliegenden Fall war nach IVF/ICSI und Laserbehandlung der Zona pellucida („assisted hatching“) eine monochoriale, diamniote Geminigravidität eingetreten, bei der es wohl zu einer partiellen Verschmelzung der Embryonen kam. Pränatal wurde in der 13 + 3 SSW im Rahmen einer detaillierten Ultraschalldiagnostik der Verdacht auf eine Diskrepanz der Geschlechter der Gemini gestellt, der sich in den Folgeuntersuchungen bestätigte. Post partum war das phänotypische Geschlecht des einen Zwillings weiblich und des anderen männlich. Die Histologie der Plazenta bestätigte die monochorialen, diamnioten Eihautverhältnisse. Postnatal erfolgte die zytogenetische Analyse der Zwillinge in verschiedenen Geweben. Die Karyotypisierung an Blutlymphozyten ergab für den weiblichen und männlichen Zwilling jeweils ein Mosaik aus männlichen und weiblichen Zellen. In den Mundschleimhautzellen zeigte sich für beide Neugeborene ein unauffälliger männlicher bzw. weiblicher Karyotyp. Die Diagnostik an Urothelzellen war für das männliche Neugeborene ebenfalls unauffällig und zeigte für das weibliche Neugeborene ein schwaches gonosomales Mosaik mit XX- und XY-Konstellation. Zumindest für Blutlymphozyten konnte die Diagnose der Chimären bewiesen werden. oocyte (monozygote) and have identical sex. With monozygotic twins one of three types of placentation and fetal membrane setup occur depending on the timing of separation into two individuals: One third are dichorionic and diamniotic, occurring when separation takes place during the cleavage or morula stages. In two thirds of monozygotic twin pregnancies separation of 


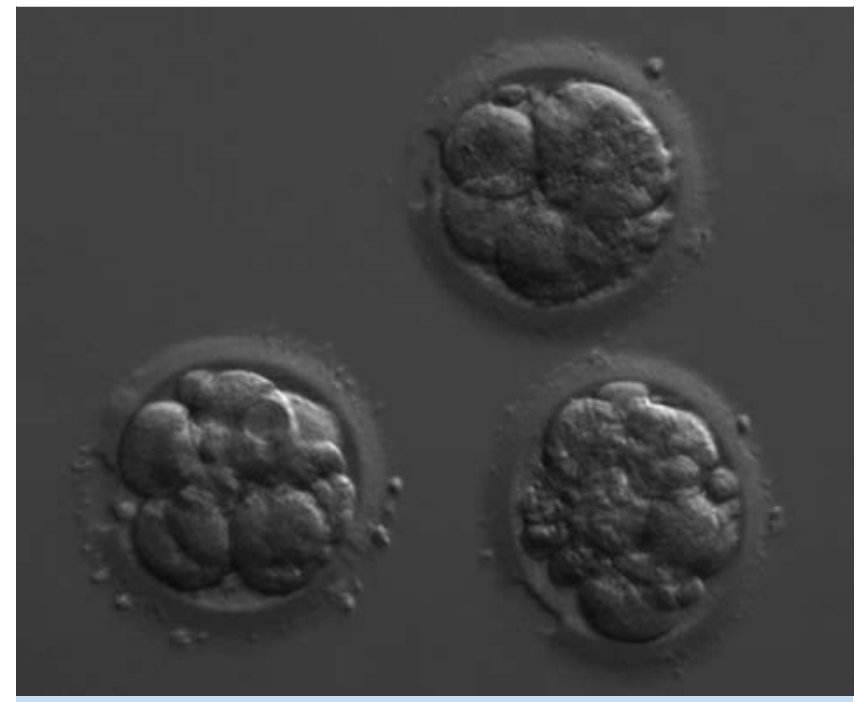

Fig. 1 Three embryos at 6 and 8 cell stages before transfer (culture day 3).

the embryoblast occurs during the blastocyst stage, resulting in monochorionic diamniotic placentation. When separation happens only after formation of the amniotic cavity, monozygotic twins with monochorionic, monoamniotic placentation occur ( $1 \%$ of monozygotic twins).

We present a case of monochorionic, diamniotic twins following in vitro fertilisation with intracytoplasmic sperm injection (IVF/ ICSI), in which discordant sex was detected on detailed antenatal ultrasound.

\section{Case Presentation}

$\nabla$

A 36-year-old patient underwent long protocol IVF/ICSI in view of primary male factor infertility. 16 oocytes were inseminated by intracytoplasmic sperm injection (ICSI). Intrauterine transfer of two embryos at 8 cell stage and one at 6 cell stage was performed on the third day after follicle puncture ( $\bullet$ Fig. 1 ).

Cleavage of the three transferred embryos was timely and the cumulative embryo score (CES) after Steer [1] of $44(16+16+12)$

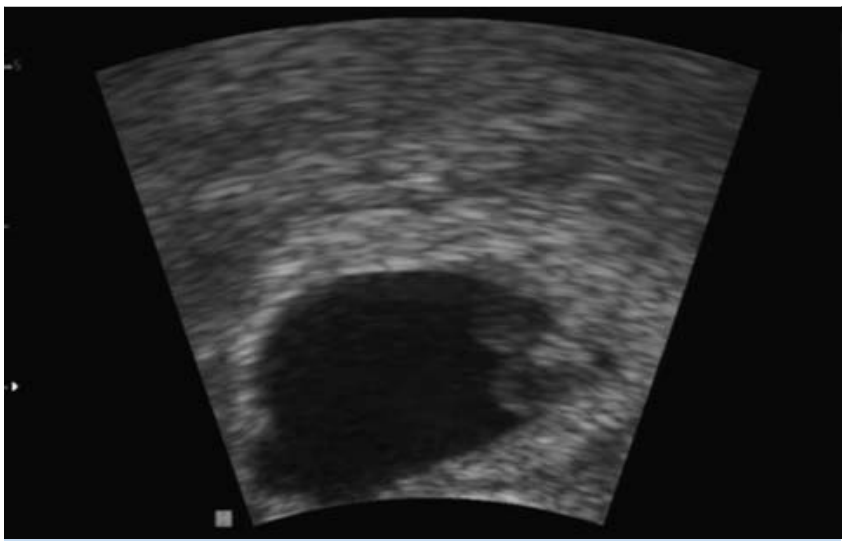

Fig. 2 Image from the first ultrasound performed at $5+3$ weeks gestation showing one chorion and two yolk sacs.

was reduced since embryonic morphology was limited (blastomeres of differing size and fragmentation). Laser treatment of the zona pellucida was carried out on all the embryos before transfer to support hatching for successful implantation ("assisted hatching").

The first ultrasound examination, at $5+3$ weeks gestation, documented a monochorionic twin pregnancy ( $\bullet$ Fig. 2).

On detailed transabdominal and transvaginal ultrasound of the twins at $13+3$ weeks gestation discordant sex was suspected (- Figs. 3 and 4). This was confirmed on subsequent examinations at $17+5$ and $21+6$ weeks gestation. Fetal anatomy was otherwise normal.

The patient decided against further invasive investigation for lack of clinical consequence.

The pregnancy was uneventful apart from autoimmune thyroiditis, which was diagnosed before pregnancy and treated with thyroxin.

The twins were delivered by primary caesarean section at $36+6$ weeks gestation with mild polyhydramnios. Apgar scores and $\mathrm{pH}$ values were normal. Post partum both twins were phenotypi-

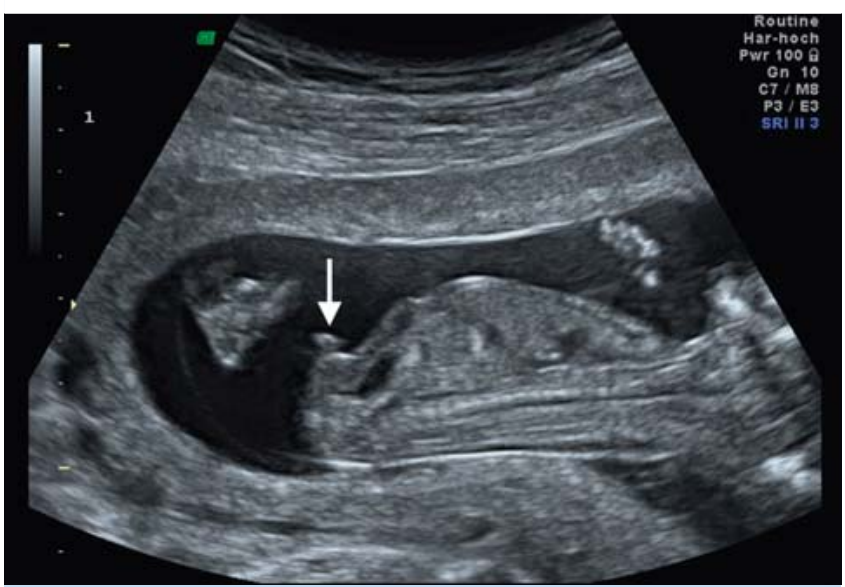

Fig. 3 Ultrasound image of the first fetus in the sagittal plane showing the penis (arrow).

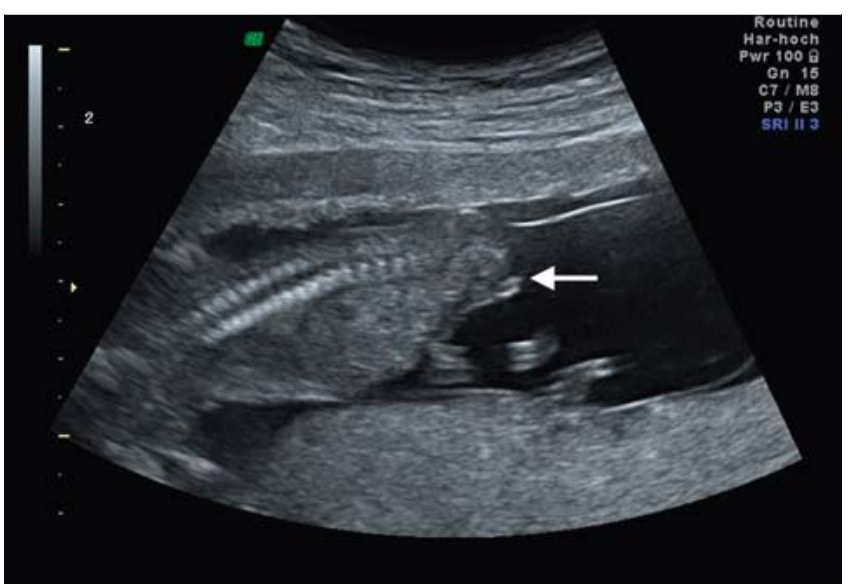

Fig. 4 Ultrasound image of the second fetus in the sagittal plane showing the clitoris (arrow). 
Table 1 Results of karyotyping and fluorescent in situ hybridisation (FISH) analysis

\begin{tabular}{|c|c|c|}
\hline Cell type & Method & Result \\
\hline \multicolumn{3}{|c|}{ Mosaic of the phenotypic female twin: } \\
\hline Blood lymphocytes (Mesenchyme) & Conventional chromosomal analysis & $46, \mathrm{XY}[18]: 46, \mathrm{XX}[12]$ \\
\hline Blood lymphocytes & $\mathrm{FISH}$ & $\mathrm{X} 0[3]: \mathrm{XXY}[3]: \mathrm{XXYY}[1]: \mathrm{XY}[155]: \mathrm{XX}[138]$ \\
\hline Oral mucosa (Ectoderm) & $\mathrm{FISH}$ & $\mathrm{XY}[0]: X X[200]$ \\
\hline Urothelium (Endoderm) & FISH & $X Y[5]: X X[95]$ \\
\hline \multicolumn{3}{|l|}{ Mosaic of the phenotypic male twin: } \\
\hline Blood lymphocytes & Conventional chromosomal analysis & $46, X Y[19]: 46, X X[11]$ \\
\hline Blood lymphocytes & $\mathrm{FISH}$ & $X Y[201]: X X[99]$ \\
\hline Oral mucosa & FISH & $X Y[200]: X X[0]$ \\
\hline Urothelium & FISH & $X Y[47]: X X[0]$ \\
\hline
\end{tabular}

cally normal. One twin had normal male external genitalia with bilateral descended testes. The other had normal female external genitalia and a uterus and left ovary measuring $9 \mathrm{~mm}$ were demonstrated on abdominal ultrasound; the right ovary could not be visualised. In addition, a double renal pelvis was found on the right. Placental histology confirmed the monochorionic, diamniotic situation.

Cytogenetic analysis on heparinised blood was performed on the first day of life for the female twin, and on the 6th day of life for the male twin. EDTA blood, urine and oral mucosal cells were taken on the 21 st day of life from both twins (for results see $\square$ Table 1).

A lineage analysis was performed for both twins on EDTA blood from the 21st day of life to exclude a chimerism. This showed an identical signal pattern for both children: More than two alleles were found in 4 of the 10 short tandem repeat (STR) systems examined proving the diagnosis of chimerism, at least for blood lymphocytes.

\section{Discussion}

\section{$\nabla$}

Chimerism is defined as genetically different cells/tissues from more than one zygote, occurring in one individual [2]. To date 15 cases of monochorionic, dizygotic twins with chimerism have been described [3-14]. Most of these cases were blood chimerisms due to twin-twin transfusion in the presence of a common placenta $[3,5-8,10-13]$; in this case chromosomal analysis of mucosa or skin biopsy is consistent with phenotypic sex.

In the current case FISH was carried out on urothelium from both twins. The female twin was found to have a gonosomal constellation of XY[5],XX[95], so that a gonosomal mosaic could not be excluded.

Only five cases of monochorionic, dizygotic twins following spontaneous conception have been described in the literature to date. These include two sets of twins with differing sex [7,15], two sets with one trisomy 21 each [10] and one case with trisomy 13 in one twin [5].

As in our case, the majority of those described previously have occurred in the context of infertility treatment with ovarian stimulation and artificial insemination i.e. IVF or IVF + ICSI [3,6, $8,9,11-14,16]$. Typically numerous embryos were transferred simultaneously. It is thought that fusion/amalgamation of the outer cells is possible at the late morula stage (from day 4) with the inner cells remaining unchanged [13-15]. This type of fusion has been described in vitro in mouse blastocysts [17]. Procedures such as "assisted hatching", where the zona pellucida is opened artificially, and other factors including culture environment and simultaneous intrauterine transfer of multiple embryos may be further predisposing factors for embryo amalgamation $[9,14,18]$. When oocyte insemination is by ICSI, simultaneous fertilisation of the oocyte with two different spermatozoa before disintegration of the second polar body with subsequent amalgamation followed by separation into two individuals is almost impossible. As part of IVF/ICSI treatment correct oocyte insemination following microinjection with one sperm cell is documented, as is confirmation of both pronuclei and embryo development. Thus embryo amalgamation with subsequent twin separation is only possible after embryo transfer. Separation of fused embryos can only occur after implantation (at least 5 days after fertilisation), as is the case with monochorionic, diamniotic twins, and only after development of the trilaminar germ disc in the second week after fertilisation. Both lymphocytes and cells of the urinary tract originate from mesenchyme and endoderm and are therefore tissues originating from the trilaminar germ disc. In the current case the gonosomal mosaic constellation was found in these two tissues of the female infant, and in the male infant's lymphocytes. The finding could not be demonstrated on oral mucosal cells, which originate from ectoderm.

Such chimerisms may occur more often than is commonly assumed since similar constellations in same sex twins will go undetected, leading to underestimation of monochorionic, dizygotic pregnancies. The possibility of discrepant cytogenetic findings in monochorionic twins should be taken into consideration when performing invasive antenatal investigation. It is almost impossible to assign karyotype or molecular genetic results from villus sampling of a monochorionic placenta to a particular twin. The same is true for fetal blood and blood samples from newborns in the first weeks of life because of twin-twin transfusion, which occurs commonly with monochorionic placenta. Amniocentesis therefore appears more reliable for allocating genetic results to specific twins in this context.

Apart from chimerism, the differential diagnosis of discordant sex on antenatal ultrasound includes endocrine causes including virilisation of a female fetus, e.g. adrenogenital syndrome. Disorders of sexual development such as complete androgen insensitivity syndrome (CAIS) can result in a cytogenetically male fetus having a female phenotype [19-22].

Lineage tracing was repeated on both infants in order to differentiate between blood chimerism - due to mixing of blood via twintwin transfusion - and true chimerism. An identical signal pattern was found in 4 of the 10 STR systems analysed confirming chimerism at least for blood lymphocytes. 


\section{Consent}

$\nabla$

The patient gave written consent for the publication of this case report and relevant images.

\section{Conflict of Interest}

$\nabla$

None.

\section{References}

1 Steer CV, Mills CL, Tan SL et al. The cumulative embryo score: a predictive embryo scoring technique to select the optimal number of embryos to transfer in an in-vitro fertilization and embryo transfer programme. Hum Reprod 1992; 7: 117-119

2 Behringer RR. Human-animal chimeras in biomedical research. Cell Stem Cell 2007; 1: 259-262

3 Smeets D, van Vugt JM, Gomes I et al. Monochorionic dizygous twins presenting with blood chimerism and discordant sex. Twin Res Hum Genet 2013; 16: 799-801

4 Chen K, Chmait RH, Vanderbilt D et al. Chimerism in monochorionic dizygotic twins: case study and review. Am J Med Genet A 2013; 161: 1817-1824

5 Ramsey KW, Slavin TP, Graham G et al. Monozygotic twins discordant for trisomy 13. J Perinatol 2012; 32: 306-308

6 Assaf SA, Randolph LM, Benirschke K et al. Discordant blood chimerism in dizygotic monochorionic laser-treated twin-twin transfusion syndrome. Obstet Gynecol 2010; 116 (Suppl. 2): 483-485

7 Hackmon R, Jormark S, Cheng Vet al. Monochorionic dizygotic twins in a spontaneous pregnancy: a rare case report. J Matern Fetal Neonatal Med 2009; 22: 708-710

8 Ekelund CK, Skibsted L, Sogaard K et al. Dizygotic monochorionic twin pregnancy conceived following intracytoplasmic sperm injection treatment and complicated by twin-twin transfusion syndrome and blood chimerism. Ultrasound Obstet Gynecol 2008; 32: 832-834
9 Walker SP, Meagher S, White SM. Confined blood chimerism in monochorionic dizygous (MCDZ) twins. Prenat Diagn 2007; 27: 369-372

10 Shalev SA, Shalev E, Pras E et al. Evidence for blood chimerism in dizygotic spontaneous twin pregnancy discordant for Down syndrome. Prenat Diagn 2006; 26: 782-784

11 Aoki R, Honma Y, Yada Yet al. Blood chimerism in monochorionic twins conceived by induced ovulation: case report. Hum Reprod 2006; 21 : 735-737

12 Williams CA, Wallace MR, Drury KC et al. Blood lymphocyte chimerism associated with IVF and monochorionic dizygous twinning: case report. Hum Reprod 2004; 19: 2816-2821

13 Souter VL, Kapur RP, Nyholt DR et al. A report of dizygous monochorionic twins. N Engl J Med 2003; 349: 154-158

14 Miura K, Niikawa N. Do monochorionic dizygotic twins increase after pregnancy by assisted reproductive technology? J Hum Genet 2005; 50: $1-6$

15 Nylander PP, Osunkoya BO. Unusual monochorionic placentation with heterosexual twins. Obstet Gynecol 1970; 36: 621-625

16 van Dijk BA, Boomsma DI, de Man AJ. Blood group chimerism in human multiple births is not rare. Am J Med Genet 1996; 61: 264-268

17 Tarkowski AK, Wojewodzka M. A method for obtaining chimaeric mouse blastocysts with two separate inner cell masses: a preliminary report. J Embryol Exp Morphol 1982; 71: 215-221

18 Strain L, Dean JC, Hamilton MP et al. A true hermaphrodite chimera resulting from embryo amalgamation after in vitro fertilization. N Engl J Med 1998; 338: 166-169

19 Pinhas-Hamiel O, Zalel Y, Smith E et al. Prenatal diagnosis of sex differentiation disorders: the role of fetal ultrasound. J Clin Endocrinol Metab 2002; 87: 4547-4553

20 Katorza E, Pinhas-Hamiel O, Mazkereth R et al. Sex differentiation disorders (SDD) prenatal sonographic diagnosis, genetic and hormonal work-up. Pediatr Endocrinol Rev 2009; 7: 12-21

21 Pajkrt E, Petersen OB, Chitty LS. Fetal genital anomalies: an aid to diagnosis. Prenat Diagn 2008; 28: 389-398

22 Efrat Z, Perri T, Ramati E et al. Fetal gender assignment by first-trimester ultrasound. Ultrasound Obstet Gynecol 2006; 27: 619-621 